\title{
Recent Trends in Gender Wage Inequality in the United States
}

\author{
Jing Shen, Post-doctoral Fellow \\ The Prentice Institute for Global Population and Economy \\ University of Lethbridge \\ 4401 University Drive West \\ Lethbridge, Alberta, Canada T1K 3M4
}

Doi:10.5296/jsr.v5i1.6093 URL: http://dx.doi.org/10.5296/jsr.v5i1.6093

\begin{abstract}
In this review article, I focus on the changing trends and main explanations of gender wage inequality in the United States. First, I briefly describe the most prominent trends in gender wage inequality since the end of the 1970s. I then summarize theoretical explanations of these trends at both the individual level and the structural level. At the individual level, neoclassical human capital theory highlights the sharp increase in women's educational attainment as the reason for the narrowing trend in the gender pay gap, while using the gender differences in educational and work experience to explain the persistence of this gap. An emerging debate about the human capital explanation is whether the observed gender disparities in educational and work experiences are the result of individuals' personal choices or the consequences of social construction. I subsequently numerate three main sociological theories - gendered socialization, statistical discrimination, and social capital - to show how social values, conventions, and systems shape individuals' "free" choices. At the structural level, I emphasize the fundamental shift in the industrial structure and employment arrangements driven by the skill-biased technology change (SBTC) and globalization. I conclude this article by summarizing both the positive and the worrisome trends in gender wage inequality, and by outlining policy implications for achieving gender equity in the future development of the U.S. labor market.
\end{abstract}

\section{INTRODUCTION}

Until the late 1970s and early 1980s, the female-to-male earnings ratio-the ratio of the median annual earnings of women who worked year-round, full-time and the median annual earnings of comparable men (Roos and Gatta 1999) - had remained constant at around 60 percent in the U.S. labor market (Blau and Kahn 2007). Since then, the ratio has changed dramatically. Despite some variation in the pace of change, the past three decades have witnessed a significant increase in the ratio of women's earnings to men's earnings. According to scholarly observations (Blau and Kahn 2007; Leicht 2008), the overall gender gap in earnings decreased by approximately 20 percent from the end of 1970s to the first decade of the current century, as women's average earnings increased from around 60 to 80 percent of men's average earnings during this period. Decoding the recent trends in gender wage inequality is important because it facilitates an understanding of the intricate, multi-faceted change in the labor market in recent decades, particularly in the context of the deepening inequality in the U.S. labor market (Blau and Kahn 2007).

In this review article, I first highlight the most prominent trends in gender wage inequality 
since the end of 1970s. I then explore the possible theoretical explanations of these trends at both the individual level and the structural level. At the individual level, the dominant explanations derive from human capital theory, which describes two factors that affect these trends. First, in the United States, the number of bachelor's degrees awarded to women has outpaced the number awarded to men since the early 1980s (Buchmann and DiPrete 2006), indicating that higher education has indeed played an important role in the narrowing gender pay gap. However, gender differences still exist in the selection of colleges and universities, public versus private educational institutions, and more importantly, majors. As a result, the different educational paths resulting from these selections channel men and women into jobs with different starting salaries, and also lead them to different opportunities to access on-the-job training. An emerging debate among proponents of the human capital theory centers on whether the observed gender disparities in educational paths and on-the-job training opportunities are the result of individuals' personal choices or the consequences of discrimination.

At the structural level, the skill-biased technology change (SBTC) and globalization have triggered fundamental changes in the industrial structure, employment relations, and skill requirements of occupations. Accompanied by the sectoral shift from manufacturing to services, permanent employment (which was prevalent before the 1970s) has been increasingly replaced by flexible employment arrangements in the form of part-time, precarious jobs. Unionized blue-collar jobs in the manufacturing sector, which were once the basis of the formation of a large middle class, have declined significantly. The polarization of job opportunities in the United States has become increasingly evident, as jobs have expanded in both high-skill, high-wage occupations and low-skill, low-wage occupations (Autor 2011). This pattern was strengthened during the Great Recession as traditionally "good" jobs in the automobile industry and related manufacturing sectors disappeared to a great extent (Kalleberg 2011). Changes at the structural level have both positive and negative impacts on gender wage inequality, which will be articulated in this review.

In the concluding section, I summarize both the positive and the worrisome trends in gender wage inequality reviewed in this article. I also outline policy implications for achieving gender equity in the future development of the U.S. labor market.

\section{OVERVIEW OF RECENT CHANGES IN GENDER WAGE INEQUALITY}

Scholarly investigation of the gender wage gap usually focuses on full-time workers in order to compare male and female workers who are as similar as possible. Using government statistics, Blau and Kahn (2007) computed the female-to-male earnings ratios of full-time workers using both annual and weekly earnings, as shown in Figure 1. Both data series tell the same story; namely, on average, women earned around 60 percent of men's earnings from 1955 to the end of the 1970s. In the following decade (the 1980s) the ratio increased noticeably, and by the end of the 1980s, both the annual and weekly earnings ratios had reached 70 percent. During the 1990s, however, both lines flattened, indicating a slower increase in women's earnings (relative to men's) in this period. Data from the U.S. Bureau of Labor Statistics (BLS) on the annual earnings of full-time workers reveal a similar trend. In 1955, women workers earned 64 percent of men's salaries; the ratio fell slightly to 59 percent by 1975, and then rose to 71 percent by 1995 (Roos and Gatta 1999). The female-to-male earnings ratio continued to rise in the early 2000s, especially during the Great Recession. According to Blau and Kahn's (2007) calculation using data drawn from the Panel Study of Income Dynamics (PSID), for example, the wage differential between male and female full-time workers was $20 \%$ at the beginning of this century. This gap has further narrowed to 18 percent in 2009, as shown in the AAUW's (American Association of University Women) 
2012 report (Corbett and Hill 2012). BLS data released in June 2009 also show that women's employment rate exceeded men's by 2.5 percent. However, scholars think that it is too early to tell whether this recent increase indicates "a strong, long-run trend towards convergence in male-female earnings" (Blau and Kahn 2007:9; see also Roos and Gatta 1999:95). This is because women's higher employment rate during the recession does not necessarily reflect their earnings gains relative to men's, particularly if women have a higher employment rate because they are more willing to take precarious contract positions (Zhang 2011).

\section{Figure 1. Female-to-Male Earnings Ratios of Full-Time Workers 1955-2003}

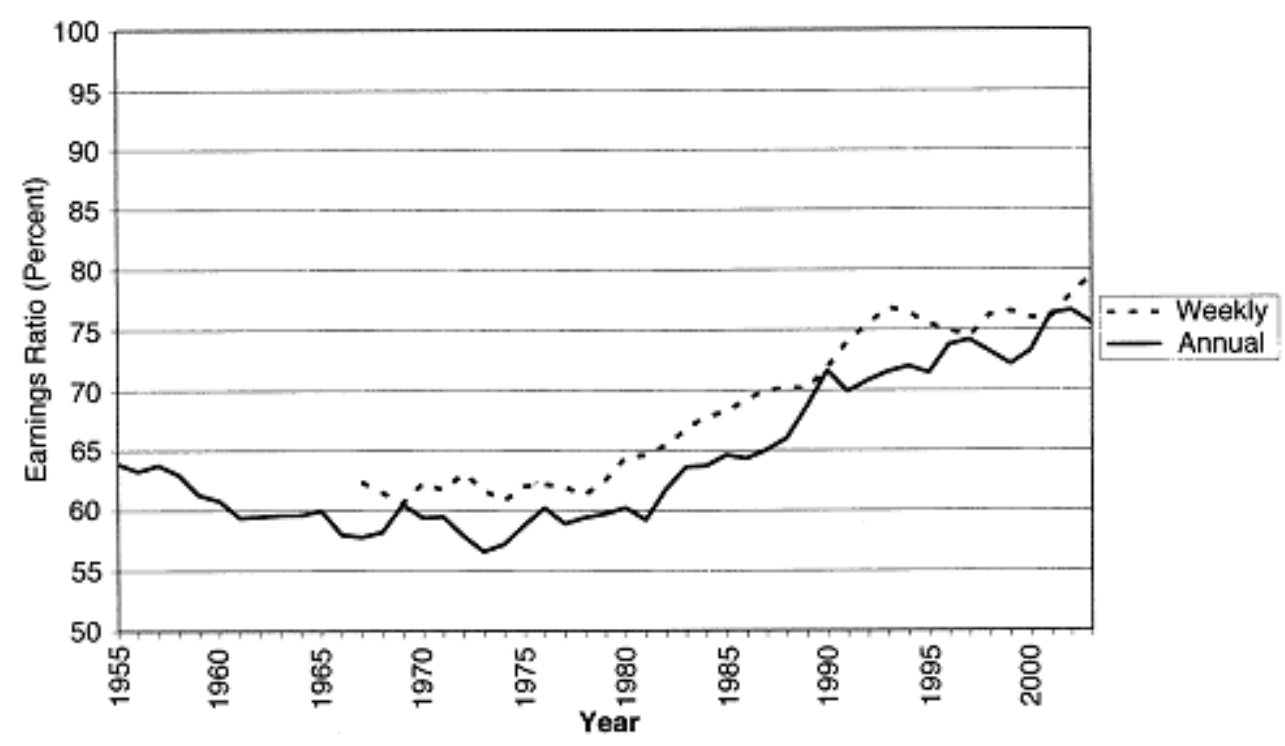

(Originally from Figure 1, Blau and Kahn 2007: 8. Blau, Francine, and Lawrence M. Kahn. 2007. The Gender Pay Gap: Have Women gone as Far as They Can? Academy of Management Perspectives, 21(1): 7-23.)

Regardless, the narrowing trend of the gender wage gap is undeniable. As Blau and Kahn (2007) noted, women's relative pay gains were initially concentrated among younger women, and then spread to women of all ages, although the gains may still be a bit larger for younger women. As the authors stated, "less-educated women have narrowed the pay gap with less-educated men and highly educated women have narrowed the pay gap with highly educated men." (Blau and Kahn 2007:7) By examining BLS and Census Microdata from 1970, 1980, and 1990, Roos and Gatta (1999) found that the gender earnings gap changed at different paces for different groups. With regard to racial differences, the gender earnings ratio for whites declined slightly between 1970 and 1980, and then rebounded notably between 1980 and 1990. For blacks, the earnings ratio was significantly higher than for whites in each census year, and increased monotonically between 1970 and 1990. By 1990, white women were earning 64 percent of their male counterparts' earnings, while black women were earning 81 percent of what black men earned (Roos and Gatta 1999:98).

Regarding age, Roos and Gatta (1999) observed that the gender gap widened as workers' ages increased. Women between the ages of 16 and 24 earned nearly 87 percent of what comparably aged men earned, whereas the ratio was 67 percent for those 35 to 39 years old, and 58 percent for those 50 to 54 years old. The earnings ratio increased slightly at retirement age, with women at 65 years old and older earning 67 percent of the male wage.

Scholars have also analyzed the gender wage gap by education. In a report by the AAUW, Corbett and Hill (2012) noted that only 11 percent of women ages 25 to 64 in the civilian 
labor force in 1970 had attended college for at least four years, but by 2010, 36 percent of women in the same age group were college graduates. Indeed, the report found that in the present labor market, working women between the ages of 25 and 64 are more likely than their male counterparts to have a college degree (36 percent of women compared with 33 percent of men) (Corbett and Hill 2012:8; originally from Table 9, the U.S. Department of Labor 2011). However, the gender wage gap persists among those with high levels of education: female college graduates still earn, on average, less than their male counterparts. Among those working full time, women earned $\$ 35,296$ on average, while men earned $\$ 42,918$ on average. As Corbett and Hill (2012) documented, one year after college graduation, women's earnings had already fallen behind men's earnings. In 2009, women who were one year out of college and working full time earned, on average, 82 percent of what their male peers earned. Carnevale and her collaborators (2011) estimated that over the course of a lifetime, college-educated women working full time earn more than a half million dollars less than their male peers. The historical pay gap has contributed to a gender poverty gap among the elderly, with 11 percent of elderly women, but only 6 percent of elderly men living in poverty in 2011 (DeNavas-Walt et al. 2012).

In short, gender wage inequality remains, although the gap has narrowed significantly in recent decades. The trends in gender wage inequality reflect not only the changing individual characteristics of men and women in the labor force, but also complex shifts at the macro level, such as changes in the industrial structure, labor market structure, occupational structure, and employment relations. In the following sections, I review individual-level and structural-level theoretical explanations of the trends outlined above.

\section{INDIVIDUALIST EXPLANATIONS: HUMAN CAPITAL THEORY}

\section{The Central Role of Education: Women's Inroads into High-Paying Jobs}

Scholars have reached a consensus about the unprecedented importance of education for an individual's career prospects in the era of the "knowledge economy" (Bell 1976; Card and DiNardo 2002). According to the skill-biased technology change (SBTC) hypothesis, skill polarization resulting from the emergence of new technology has been the main force driving wage inequality in the past decades. While economic returns to education continued to rise, the real wages of poorly educated workers continued to fall (Chusseau et al. 2008; Leicht 2008; Neckerman and Torche 2007). From 1979 to 1994, the real weekly earnings of U.S. college graduates rose by 5 percent, while the earnings of U.S. high school graduates fell by 20 percent (Morris and Western 1999). In 1963, the hourly wage of the typical college graduate was approximately 1.5 times the hourly wage of the typical high school graduate. By 2009, this ratio had risen to 1.95 . The entirety of this 45 percentage point rise occurred after 1980 (Autor 2011).

Given the traditional male predominance in blue-collar jobs, the SBTC might be expected to have benefited women more than men. According to Buchmann and DiPrete (2006), the number of bachelor's degrees awarded to females increased steadily from 1959 to 2004, and women have earned more bachelor's degrees than men since the beginning of the 1980s. In 2004, the number of women who held bachelor's degrees was almost 20 percent higher than the number of male bachelor's degree holders. As Leicht (2008) summarized, women have surpassed men in college enrollment, and are at or near parity in representation in most professional schools. Morris and Western (1999) also found that while the number of women completing college has risen continuously in the postwar period, the college degree completion rate for men peaked and then declined after the 1980s. In addition, the finding that women are more likely to use computers at work suggests that women as a group may have benefited from computerization more than men, particularly because computers have 
restructured work in ways that de-emphasize physical strength (Blau and Kahn 2007; Weinberg 2000).

Consequently, while women's overall real earnings have increased due to their increasing participation in the labor market, the greatest real wage increases were concentrated among the college educated, according to Leicht (2008). In 2006, 38 percent of working women were employed in management, professional, and related occupations, while only 32 percent of working men were in those occupational categories in the U.S. labor market (Bureau of Labor Statistics 2006). As Leicht noted, "the hiring of new associates for under-represented groups (and especially women) is no longer a significant barrier to equality in the professional labor market" (Leicht 2008:248). In short, because the SBTC has multiplied the economic returns to higher education, women's increasing participation in high-status, high-pay professional and managerial positions was a primary reason for the decrease in the wage gap between men and women.

\section{Persistent Gender Wage Inequality: Neoclassical Human Capital Explanations}

Nevertheless, the pay gap between men and women persists. Within each educational level, male workers consistently out-earn their female counterparts. As Roos and Gatta (1999) documented, in 1990, college-educated women earned $\$ 25,000$ per year on average, an income comparable to that of high-school-educated men, and only $\$ 5,000$ more than a male high-school dropout. The most highly educated women (those with advanced graduate degrees) had the lowest earnings ratio relative to comparable men (64 percent). Women with the least amount of education (no schooling) had the highest ratio (80 percent), though this is largely attributed to the very low earnings of men with no schooling.

From the perspective of human capital theory, labor economists have argued that some groups are paid less because these groups have relatively low productivity, as indicated by their lower levels of human capital (Becker 1993[1964]; Card and Lemieux 1994; Darity and Mason 1998; Gill 1994). Thus, within this framework, women's lower wages (relative to men's) are seen as a measure of their lower productivity.

First, although women are more likely than men to enroll in and complete higher education, gender differences remain in multiple dimensions of educational experience. Women are more likely than men to graduate from colleges rather than universities (36 percent of women compared with 29 percent of men). Men, however, are more likely than women to graduate from "very selective" colleges (34 percent compared with 30 percent) and from public universities (51 percent compared with 45 percent) (Card and Krueger 1992; Corbett and Hill 2012). In addition, there has been little change in the fields in which men and women study (England and Li 2006). In the 2007-2008 school year, women comprised the majority of bachelor's degree recipients in fields of health care (88 percent) and education (81 percent), but were a distinct minority in the fields of engineering and engineering technology (18 percent) and computer and information sciences (19 percent) (see Figure 3, Corbett and Hill 2012:12). This difference in undergraduate majors may explain why women are more likely than men to work in business support and administrative assistance occupations and as teachers, social services professionals, as well as nurses and other health care providers. Men, in contrast, are more likely than women to work in business and management, computer and physical science occupations, and as engineers. Given the differences in pay between these types of jobs, graduates who earned degrees in female-dominated majors tend to obtain jobs that pay less than the jobs held by graduates who earned degrees in male-dominated majors.

Second, on average, women have significantly less work experience than their male counterparts. Mincer and Polachek (1974) highlighted the role of labor market experience in the gender pay gap. Due to the traditional division of labor by gender in the family, women 
tend to accumulate less labor market experience than men. Using data drawn from the PSID in 1998, Blau and Kahn (2007) found that, on average, women had 3.5 fewer years of full-time work experience than men, which explained 11 percent of the gender gap in wages. Further, because women anticipate shorter and more discontinuous work lives, they have lower incentives to invest in market-oriented formal education and on-the-job training (Becker 1993[1964]). Using data about college graduates in the 2007-2008 cohort, Corbett and Hill (2012) found that differences in the number of hours worked also affected earnings and contributed to the gender pay gap. One year out of college, in 2009, women in full-time jobs reported working 43 hours per week on average, while men in full-time jobs reported working an average of 45 hours per week. Beyond that, women are also more likely than men to relocate for their spouses' jobs, and thus interrupt their work experience (McKinnish 2008).

As a result, women may avoid jobs requiring large investments in skills that are unique to a particular enterprise, because the returns to these investments are reaped only as long as the individual remains with the same employer. At the same time, employers may be reluctant to hire women for such jobs because the firm bears some of the costs of firm-specific training, and may fear not getting a full return on their investment. Based on an analysis of CPS data series from 2004 to 2009, Zhang (2011) calculated that while the average return on investment (ROI) ratio for education was consistently higher for women (1.35) than for men (around 0.87), the economic returns to experience were much lower for women than for men (around 0.007 versus 0.02). Using data drawn from the PSID in 1998, Blau and Kahn (2007) also found that, on average, women's work experience was 3.5 years less than men's work experience, which explained 11 percent of the gender gap in wages.

\section{The Sociological Adaptation of Human Capital Theory}

Neoclassical human capital theory seems to imply that the gender wage gap is fair, because women themselves choose majors that lead to lower-paying jobs, and choose to limit their investments in work experience due to their family obligations (Becker 1993[1964]). However, the "free will" associated with the choices women make is shaped by social values, conventions, and systems. Namely, the aforementioned differences in educational and work experiences between men and women result from socially constructed gender roles, rather than biological differences between the two groups. Among others, three approaches - gendered socialization, statistical discrimination, and social capital - represent the sociological understanding of the sources of gender differences in labor market performance.

\section{Gendered socialization}

Human capital theory emphasizes individual investment choices, indicating that people make decisions about the investment of human capital based on rational calculations of the costs and benefits. In other words, it is women's own preferences for lower-paying but less intensive, more flexible, and "family-compatible" jobs that lead to women's inferior status in the earning hierarchy.

Sociologists are interested in the underlying mechanism that drives women to "prefer" lower-paying jobs, and have found that women's seemingly free choices are essentially shaped by the process of gendered socialization imposed by patriarchal culture (Acker 1990, 2004; Reskin and Roos 1990; Smith 1994). To explain why females are more likely to obtain "female" jobs, for example, Jacobs (1989) noted that gendered socialization occurs throughout life, from early family education to school education, and to formal and informal training in the labor market.

Using the National Educational Longitudinal Study of 1988 (NELS-88), Correll (2001) 
developed a supply-side model of gender differences in early career-relevant decisions. Correll focused on high school students' perceptions of their mathematical competence and how these perceptions, controlling for actual ability, influenced the decisions made along the path to careers in professions that require quantitative skills. Her findings show evidence of widely shared cultural beliefs about boys' and girls' abilities to fulfill quantitative tasks (i.e., mathematical questions). During the socialization process, these cultural beliefs contribute to the construction of gendered views, which lead males and females to evaluate their competence at career-relevant tasks differently. While males are inclined to overestimate, females are inclined to underestimate their own mathematical abilities. Because females are less likely than males to perceive that they are good at solving mathematical problems, they are more likely to reduce their efforts toward as well as interest in activities requiring quantitative skills. Consequently, women are less likely than men to persist on a career path that requires competence in mathematical tasks.

Using data from the 1957 and 1992 waves of the Wisconsin Longitudinal Survey, Halaby (2003) found that men are less risk averse and express stronger preferences for high-return, high-risk "entrepreneurial" job values, while women are more risk averse and express stronger preferences for low-return, low-risk "bureaucratic" job values. According to Halaby, this difference emerges because the socialization process men experience is oriented toward a future of economic independence rooted in the labor market, whereas the socialization process women experience is oriented toward a future of economic dependence rooted in a stable marriage.

In sum, the theory of gendered socialization asserts that while men and women have different preferences in terms of the selection of undergraduate majors and subsequent career paths, these seemingly "free" choices reflect the social expectations attached to gender roles.

Statistical discrimination

Although measurable differences in human capital explain a large portion of the gender pay gap, about one-third of the gap remains when all human capital factors are controlled (Corbett and Hill 2012). In their analysis of PSID data, Blau and Kahn (2007) found that if women had the same human capital characteristics (including education and experience), racial composition, industry and occupational distribution, and union coverage as men, the adjusted female-to-male earnings ratio would still only reach 91 percent.

In intra-occupational comparisons, women also earn less than men (Tomaskovic-Devey et al. 2006). Based on BLS data and census data from the 1970s through the 1990s, Roos and Gatta (1999) observed that in male-dominated occupations women earned significantly less than men. For example, female air traffic controllers earned 67 percent of the earnings of their male counterparts, and female physicians earned only 52 percent of what male physicians earned. The pay gap also existed in female-dominated occupations. Among dental hygienists, women earned 79 percent of men's salaries; and among licensed practical nurses, women earned 87 percent of men's earnings.

The above studies suggest that the portion of the gender pay gap that cannot be explained by human capital theory may be due to discrimination. Under the statistical-discrimination model, because it is costly to measure individual productivity before hiring, employers use an estimate based on formal and/or informal data gathering to predict how individuals will perform. Given those assumptions, profit-driven employers will therefore reserve jobs with high replacement costs for members of the group with the greater expected productivity (Bielby and Baron 1986; Budig and England 2001). Indeed, a common explanation given by employers for gender differentials is that men and women differ with regard to abilities that may not always be measurable or observable, and employers need to assign men and women to different jobs based on their average productivity. Using data on 290 economic 
establishments in California collected by the California Occupational Analysis Field Center of the US Employment Service between 1964 and 1979, Bielby and Baron (1986) demonstrated that even within the same occupational category, it was a common practice that employers assigned different job tasks to male and female employees.

Empirical studies, however, show that statistical discrimination does not serve as a proper measurement of men's and women's average productivity. In a case study of the top five symphony orchestras in the United States, a switch to a blind audition policy substantially increased the probability that a woman would advance out of the preliminary rounds and be the winner in the final round. According to Goldin and Rouse (2000), this switch explained 25 percent of the recent increase in the proportion of women in these symphony orchestras, from less than 5 percent of the musicians in 1970 to 25 percent in 1996.

The case of Lucky Stores described by Blau and Kahn (2007) supported Goldin and Rouse's (2000) finding about the ineffectiveness of using statistical discrimination to measure employee's productivity. Sex discrimination was found to be the standard operating procedure "with respect to placement, promotion, movement to full-time positions, and the allocation of additional hours" in Lucky Stores (Blau and Kahn 2007: 14). Although there was little difference in the wages of male and female workers within each type of job, women were much more likely to be assigned to lower-paying jobs, even when they had the same level of education and experience as their male co-workers. A store manager testified that this difference was due to employees' own preferences and choices. However, after the company lost the lawsuit and affirmative actions were enforced in the workplace, job segregation between men and women declined significantly. This example casts doubt on the assertion that women choose poorly paid jobs solely out of self-interest (Blau and Kahn 2007:15).

Statistical discrimination also leads to gender differences in employees' access to on-the-job training opportunities. Using data from the 1989 North Carolina Employment and Health Survey, Tomaskovic-Devey and Skaggs (2002) demonstrated that women lacked access to human capital advancement after they entered the labor market because on-the-job training was usually conducted informally, based on the employer's and co-workers' perceptions and expectations of the new employee. If the employer and co-workers perceived that a female employee should take a "female" job, this female employee would be very unlikely to be trained for a "male" job. A study of law school graduates from the University of Michigan (Wood et al. 1993) is a helpful illustration in this regard. Wood and his collaborators found that the pay gap between women and men was relatively small at the outset of their careers. However, female lawyers were less likely than their male co-workers to take part in career-building cases, which were usually perceived as men's jobs, and therefore women accumulated less work experience than men. As a result, 15 years into their careers, female graduates earned only 60 percent as much as male graduates.

\section{Social capital}

The social capital explanation of gender wage inequality is based on social closure theory and homosocial reproduction theory. The social closure explanation posits that male employees attempt to monopolize privileged positions in workplaces (Reskin 1988; Tilly 1996; Tomaskovic-Devey 1993); consequently, social closure occurs within the workplace and limits women's access to the desirable positions that lead to high wages, promotions, and further skill advancement. Many sociologists have found that the formation of the gender wage gap can be understood as a process of rank segregation in which positions of higher skill, opportunity, or authority are monopolized by and for men (see Reskin's 1993 review).

The homosocial reproduction theory, in contrast, focuses on the employer side. According to Kanter (1977), positions that are higher in the organizational hierarchy are associated with a greater degree of uncertainty and interdependence, and thus require more rapid, accurate 
communication about less concrete matters (e.g., relationships between organizational means and ends, or criteria for performance evaluation). These job characteristics, in turn, place a premium on discretion and trust among workers selected to advance in the power hierarchy (Kanter 1977). The most effective way to maximize these traits and make an otherwise uncertain environment more predictable is to maintain relative social homogeneity among the employees. Kanter (1977) noted that because (white) men have historically had more power in U.S. workplaces, they benefit most from these universal tendencies toward in-group favoritism as they move up the organizational hierarchy, while women, as out-group members, face increasing inequality.

Based on the above-mentioned theories of social closure and homosocial reproduction, sociologists have developed a broad literature depicting the disadvantages women face as they seek to access "helpful" social contacts. Studies have found that women are likely to have lower entry salaries than men because women's network assistance is not as good as men's (Fernandez and Fernandez-Mateo's 2006; Fernandez and Sosa 2005; Marini and Fan 1997; Petersen et al. 2000; Reskin and McBrier 2000).

Within the workplace, women also gain less assistance via informal networks (Bridges and Villemez 1986; Campbell and Rosenfeld 1985; Podolny and Baron 1997). Research has found that work-related networks help workers gain skills, acquire legitimacy, and climb the promotional ladder (Lin 1999). These resources are important because most job training and career development are the result of informal instruction rather than continuing education and explicit on-the-job training (United States Bureau of Labor Statistics 1996). Using data from the Multi-City Survey of Urban Inequality (MCSUI), Elliott and Smith (2004) demonstrated that women who lacked network assistance were less likely to be promoted and earn higher wages in their careers, even if they had a high level of human capital at the entry stage.

Research has shown that social capital is as important as, if not more important than, human capital for an individual's success in the labor market. Despite women's remarkable advancement in educational achievements, their disadvantages in social network resources have remained significant. Thus, the social capital perspective improves the scholarly understanding of the persistence of the gender income differential.

\section{STRUCTURAL EXPLANATIONS OF GENDER WAGE INEQUALITY}

While individual-level factors such as education, statistical discrimination, and social capital explain a significant portion of the gender wage gap and the changes in this gap over time, these explanations do not depict the entire picture. A comprehensive understanding of gender wage inequality within the broader societal context is crucial in order to fully describe, evaluate, and predict these changing trends. In this section, I focus primarily on the ways in which contextual factors have shaped the changing trends of gender wage inequality.

\section{The Sectoral Shift and Occupational Polarization}

The term "post-industrial society" has been widely adopted to distinguish the current era from those before World War II (Bell 1976). The American labor market (as well as other industrialized labor markets) has undergone remarkable growth in service sector employment, and has witnessed a continuous decline in manufacturing sector employment. During the period from 1950 to 1995, the share of the labor force working in all types of service jobs increased from 60 to 80 percent, while the share working in the manufacturing sector decreased from 40 to 20 percent (see Morris and Western 1999:637 [Figure 4]). By 2009, more than 85 percent of people in the United States worked in service industries (Kalleberg 2011).

The SBTC has been one of the main forces behind this sectoral shift. Along with the rapid 
diffusion of computerization and information technology, jobs that entail repetitive production tasks and require individuals to follow precise, well-understood procedures have increasingly been codified in computer software and performed by machines. In addition, because the growth of service industries has also accelerated the trend of globalization, many of these jobs are sent electronically to worksites in developing countries to be performed by comparatively low-wage workers.

Using Census IPUMS 5 percent samples from 1980, 1990, and 2000, Autor (2011) showed that during the 1980s (1979 to 1989), employment growth by occupation rose almost uniformly with occupational skill: Occupations below the median skill level declined as a share of employment, while occupations above the median skill level increased. In the 1990s, however, a distinct pattern of polarization emerged. Employment growth was most rapid at the highest skill levels, but was also modestly positive at low skill levels (10th percentile and lower) and modestly negative at intermediate skill levels. The trend changed again at the turn of the century: From 1999 to 2007, employment growth was heavily concentrated among the lowest three deciles of occupations. Autor thus summarized that "the structure of job opportunities in the United States has sharply polarized over the past two decades, with expanding job opportunities in both high-skill, high-wage occupations and low-skill, low-wage occupations, coupled with contracting opportunities in middle-wage, middle-skill white-collar and blue-collar jobs" (Autor 2011:12). Based on his analysis of census data, Autor (2011) found that from the 1980s onward, employment and earnings rose in both high-education professional, technical, and managerial occupations and in low-education food service, personal care, and protective service occupations. Conversely, job opportunities declined in both middle-skill, white-collar clerical, administrative, and sales occupations and in middle-skill, blue-collar production, craft, and operative occupations, as shown in Figure 2.

Figure 2. Smoothed Changes in Employment by Occupational Skill Percentile,

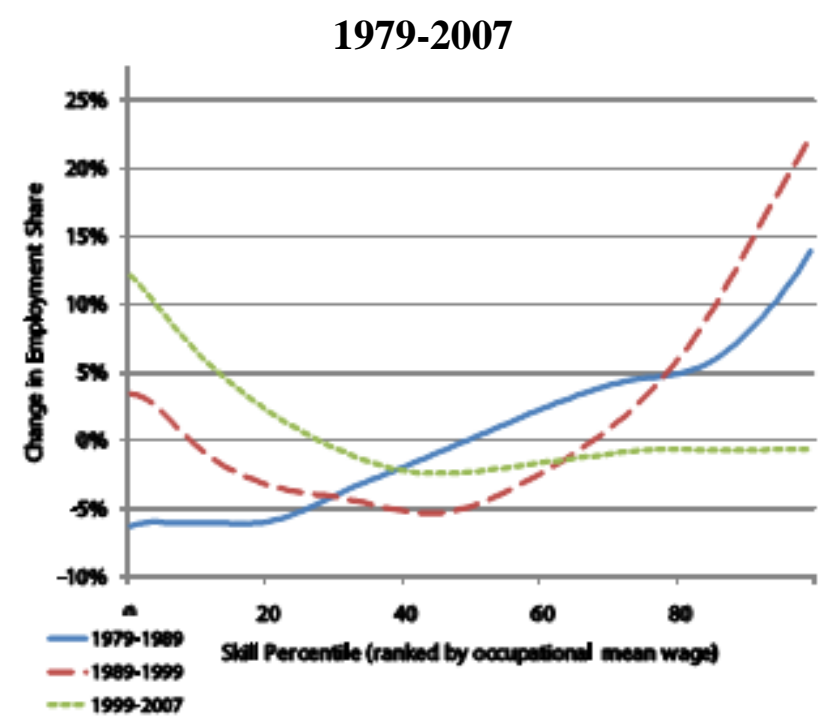

Source: Census IPUMS 5 percent samples for years 1980, 1990, and 2000, and U.S. Census American Community Survey 2008.

(Originally from Figure 1, Autor 2011: 12. Autor, David. 2011. The Polarization of Job Opportunities in the U.S. Labor Market: Implications for Employment and Earnings. Community Investments, 23(2): 11-41.) 
In the last several decades, as middle-skill, middle-class-paying jobs have been either replaced by new technology or outsourced to developing countries, services and retail trade - the sectors offering the lowest median weekly earnings-have been the fastest growing sectors (Morris and Western 1999). Services and retail trade are also characterized by lower rates of health and pension benefits, and higher rates of part-time work (Morris and Western 1999). The increase in services and retail trade became even more pronounced during the Great Recession. As Autor (2011) observed, job and earnings losses during the recession have been greater for low-education males than low-education females, and these losses have been most concentrated in middle-skill jobs. Employment fell by 8 percent in white-collar sales, office, and administrative jobs and by 16 percent in blue-collar production, craft, repair, and operative jobs. In contrast, there was essentially no net change in total employment in either high-skill professional, managerial, and technical occupations or in low-skill service occupations between 2007 and 2009. Thus, it is reasonable to conclude that the decline in middle-skill jobs has reduced the earnings and labor force participation rates of workers without a four-year college education. The impact of this decline is even more pronounced for men, because the job opportunities available to men displaced from middle-skill jobs are primarily in lower-paying service occupations.

According to Blau and Kahn's (2007) calculations, sectoral and occupational variables explain 53 percent of the gender wage gap; specifically, 27 percent of the gap is due to differences in occupational structure, 22 percent is due to differences in industry, and 4 percent is due to differences in union status. Thus, due to the polarization of the occupational structure, men's earnings losses might have contributed to the narrowing of the gender pay gap as much as, if not more than, increases in women's earnings.

\section{Flexible Employment Arrangements}

Employment arrangements have also changed to match the characteristics of the sectoral shift to the service economy. The organization of work has shifted toward more flexible arrangements. By adopting flexible work arrangements (including hiring temporary and part-time workers), firms have improved productivity and performance and reduced labor costs, thereby increasing profits. In addition, subcontracting and outsourcing non-essential functions have allowed firms to concentrate more on their core competences, and thus use their resources more efficiently (Kalleberg 2003). As Kalleberg (2003) noted, under a flexible work arrangement, managers internalize the members of their workforce who are highly trained and skilled by offering them full-time job positions and high pay, and externalize other activities and/or workers via transactional contracts. Using 1994 Employment Cost Index data collected by the Bureau of Labor Statistics, Lettau (1994) found that the average hourly earnings of part-time jobs were only 65 percent of the average hourly earnings of full-time jobs, and the difference in benefits (e.g., insurance) between the two types of jobs was even larger. Undoubtedly, there is a small but significant portion of non-standard jobs that provide workers discretion, autonomy, and high pay. Although workers in these non-standard arrangements were less likely to have fringe benefits than workers in standard arrangements, some of them earned higher wages than regular full-time workers in standard jobs (Kalleberg et al. 2000). However, on average, part-time employees still fare worse than their full-time counterparts (Kalleberg 2011).

Despite the instability and insecurity they entail, non-standard jobs meet women's needs. Part-time work provides a degree of balance between the demands of home and the paid workplace. Working part time maximizes women's ability to manage their lives, which are fragmented into distinct stages defined by the number and ages of their children, as well as other family obligations. In addition, most service jobs do not have high skill requirements, 
making it easier for women who have taken a leave from the labor force to raise children to re-enter the labor market (Smith 1994; Tilly 1996).

If flexible employment is a "pull" factor that attracts women who seek balance between work life and family life to enter the labor market, there are also "push" factors that affect the gender composition of the labor force. As mentioned above, men have continued to lose life-long, full-time, unionized, low-skill, but middle-class-paying jobs in the manufacturing sector. Those who remain in the manufacturing sector have also faced significant declines in pay. Sustaining middle-class living standards has become increasingly difficult for families following the traditional "sole breadwinner" family model. In addition, the economic insecurity of married women has also contributed to their move into the paid workforce. According to the BLS report on women's earnings in 2009 (BLS 2010), women comprised 66 percent of the part-time workers in the U.S. labor force. Of the women working part time, 74 percent were married.

Although flexible employment arrangements have increased the opportunities for women, particularly married women, to participate in the labor market (which, in turn, significantly contributed to the narrowing of the gender pay gap), these flexible employment relations have also strengthened gender wage inequality. According to Kalleberg (2001), flexible employment has further segregated peripheral, precarious jobs that are predominantly filled by women from the core, permanent jobs that are usually held by men. While some part-time workers have permanent contracts, they may still be excluded from promotion opportunities and may not be protected by human resource policies designed to encourage low turnover among core employees (Kalleberg 2001; Tomlinson, 2006). Those precarious positions thus serve as "buffer" jobs to shield core employees from job loss. The buffer-versus-core distinction became evident during the Great Recession. Using survey data collected in the United Kingdom from 2007 through 2011, Rubery and Rafferty (2013) showed that in business services, such as the financial and insurance sectors, women lost significantly more jobs than men, indicating that in these sectors women were more likely to work in buffer jobs while men were more likely to work in the core. A thorough search of the literature did not reveal any similar studies in the United States. However, because the United Kingdom and the United States share similar levels of economic development, an examination of the UK case can provide a basis for a reliable understanding of how the impacts of the recession vary by gender and by industrial sectors in American society. The trend described in the UK case shows that what drives current gender inequality in developed countries is not direct competition between the sexes, but rather "quantity changes in female vs. male sex-typed jobs" (Rubery and Rafferty 2013:416); namely, the extent to which women are more likely than men to hold precarious buffer jobs.

This trend relates to Jacobs's revolving-door theory (1989), which describes the coexistence of an enduring gendered and segmented labor market and the mobility of individual women. Using data from the 1986 Social Change and Economic Life Initiative (SCELI) in the United Kingdom, Chan (1999) modified this theory by distinguishing "female" occupations (female-dominated jobs with opportunities for upward mobility) from "heavily female" occupations in which the primarily female workforce has no promotion opportunities. Chan's findings reveal the existence of cumulative disadvantages in "heavily female" occupations. The longer an individual works in these occupations, the more difficult it is for the individual to move up in the occupational hierarchy.

Disadvantages in working in "heavily female" occupation have increasingly shown in developed countries, including the United States, particularly in the context of globalization. As Browne and Misra (2003) argued, global restructuring has played a key role in creating a pool of female immigrant workers who perform housework and childcare for extremely low 
wages. At the same time, globalization has created more high-paying professional jobs in the United States, stimulating the demand for low-paying jobs that serve the needs of professional workers (Anderson 2000; Chang 2000; de la Luz Ibarra 2000; Hondagneu-Sotelo 2001; Momsen 1999; Morris et al. 1994; Parrenas 2001; Sassen 1998). Once primarily filled by American-born racial and ethnic minority women, these low-paying jobs are now increasingly filled by immigrants, particularly immigrant women (de la Luz Ibarra 2000; Lopez-Garza and Diaz 2001; Sassen 1988; Vernez 1999).

In sum, the flexibility and low job requirements of the service sector have offered poorly educated women and women who prefer part-time work the possibility of labor market participation, which directly contributed to the sharp increase in women's labor market participation during the past 30 years. However, the pace of the decrease in the gender wage gap has not matched the increase in women's labor market participation. Part of the reason for this discrepancy is that women are more likely than men to work part time. According to BLS data, from 1970 to 2006 the percentage of working women who worked part-time remained around 25 percent, while the percentage of working men who worked part time was consistently around 10 percent (BLS 2006). Another factor underlying the persistence of the gender wage gap is likely that extremely low-paying, dead-end service jobs are more likely to be filled by women, thus dragging down the overall distribution of women's earnings (Blau and Kahn 1996).

\section{CONCLUSION AND POLICY IMPLICATIONS}

Since the 1970s, women have made tremendous progress in labor market participation and earnings. While men's real wages have generally declined since the 1970 s, this has not been the case for women. According to Morris and Western (1999), women at the $50^{\text {th }}, 70^{\text {th }}$, and $90^{\text {th }}$ percentiles have all experienced real-wage increases to varying extents. Even those at the bottom of the distribution of women's earnings held their ground and did not experience a decline in real wages. Women's economic independence has increased significantly, which has in turn increased their power in both the household and the public arena (Duffy and Pupo 1992). Even immigrant women at the bottom of the labor market report that their economic situations have improved relative to their pre-immigration situations (Sassen 1998).

Nevertheless, gender wage inequality persists. First, gendered socialization plays an essential role in shaping boys' and girls' perceptions of their abilities, interests, and career paths. One way to reduce the effects of gendered socialization would be to offer early-stage training and coaching programs in the K-12 educational system, to guide children and youths to discover their potential talents that lie beyond gender stereotypes, and to prepare them for postsecondary education.

Second, women's work performance should be evaluated fairly, independent from statistical discrimination. Fair evaluation requires transparent promotion and pay systems. Practices in the public sector have shown that women can benefit significantly from gender equity policies, such as publicizing employees' income information and adopting blind review procedures in promotion evaluation processes.

Third, if family roles prevent women from accessing on-the-job training opportunities and accumulating work experience, family-friendly policies should be implemented. For example, parental leave, especially paid leave, as well as part-time work and child care policies, have been found to increase the proportion of mothers who re-enter the work force (Hofferth 1996; Joech 1997; Kim 2013). Moderate-length paid parental leave and publicly funded child care can also increase earnings for mothers (Budig et al. 2012).

Fourth, to eliminate gender wage differentials resulting from sectoral and occupational segregation, equal opportunity employment policies must be more strongly enforced both 
across sectors and within each type of occupation.

Finally, unionization should be increased in part-time jobs. Given the rise of the service sector, including health care, education, and other sectors in which women often work, increased unionization in those jobs would improve women's wages and further narrow the gender pay gap.

It is important to note that while the gender pay gap has narrowed, overall wage inequality has increased in the past three decades. The declining earnings of men contributed significantly to the narrowing of the gender wage gap. As Morris and Western explained, "while the decline in the gender wage gap was widely seen as heralding a new era of progress for women, the sharp polarization in earnings among women, as among men, made it clear that the benefits of this new era were going to be distributed more unequally than before" (Morris and Western 1999:630). Among women workers, college-educated women "have enjoyed real economic gains and opportunities over the past few decades," while non-college-educated women "have fallen behind in both absolute and relative terms" (McCall 2001:146). These recent trends indicate that reducing gender wage inequality - as well as wage inequality in general-will require continued commitment and effort. While the average wage gap has narrowed, the gap between the richest and the poorest has widened significantly. Thus, achieving gender wage equity is still a distant goal. Future studies and policy analysis may focus on not only the average wage gap between men and women, but more importantly, also the gap between the richest men and poorest women.

\section{REFERENCES:}

Acker, Joan. 1990. "Doing Comparable Worth: Gender, Class and Pay Equity." American Journal of Sociology 96(3):761-64.

—. 2004. "Gender, Capitalism and Globalization." Critical Sociology 30(1):9-16.

Anderson, Bridget. 2000. Doing the Dirty Work: The Global Politics of Domestic Labor. London: Zed Books.

Autor, David. 2011. "The Polarization of Job Opportunities in the U.S. Labor Market: Implications for Employment and Earnings." Community Investments 23(2): 11-41.

Becker, Gary. 1993[1964]. Human Capital: A Theoretical and Empirical Analysis, with Special Reference to Education. Chicago: University of Chicago Press.

Bell, Daniel. 1976. The Coming of Post-Industrial Society: A Venture in Social Forecasting, New York: Basic Books.

Bernhardt, A., M. Morris, and M. Handcock. 1995. "Women's Gains or Men's Losses? A Closer Look at the Shrinking Gender Gap in Earnings." American Journal of Sociology, 101:302-28.

Bielby, William and James Baron. 1986. "Men and Women at Work: Sex Segregation and Statistical Discrimination.” American Journal of Sociology 91(4):759-799.

Blau, Francine, and Lawrence Kahn. 2007. "The Gender Pay Gap: Have Women Gone As Far As They Can?” Academic Management Perspective 21:7-23.

Bridges, William P. and Wayne J. Villemez. 1986. "Informal Hiring and Income in the Labor Market.” American Sociological Review, 51:574-82.

Browne, Irene and Joya Misra. 2003. "The Intersection of Gender and Race in the Labor Market.” Annual Review of Sociology 29:487-513.

Buchmann, Claudia and Thomas DiPrete. 2006. "The Growing Female Advantage in College Completion: The Role of Family Background and Academic Achievement." American 


\section{Mll Macrothink}

Journal of Sociological Research

ISSN 1948-5468

2014, Vol. 5, No.1

Sociological Review 71(4):515-41.

Budig, Michelle and Paula England. 2001. "The wage penalty for motherhood." American Sociological Review, 66:204-25.

Budig, Michelle J., Joya Misra, and Irene Boeckmann. 2012. "The Motherhood Penalty in Cross-national Perspective: The Importance of Work-family Policies and Cultural Attitudes." Social Politics 19:163-193.

Campbell, Karen E. and Rachel A. Rosenfeld. 1985. "Job Search and Job Mobility: Sex and Race Differences." Research in the Sociology of Work, 3:147-74.

Card, David, and John DiNardo. 2002. "Skill-biased Technological Change and Rising Wage Inequality: Some Problems and Puzzles.” Journal of Labor Economics 20: 733-83.

Card, David, and Alan Krueger. 1992. "School Quality and Black-white Relative Earnings: A Direct Assessment.” Quarterly Journal of Economics, vol. CVII(1):151-200.

Card, David, and Thomas Lemieux. 1994. "Changing Wage Structure and Black-white Wage Differentials." American Economic Review, 84:29-33.

Carmen, DeNavas-Walt, Bernadette D. Proctor, and Jessica C. Smith. 2012. Income, Poverty, and Health Insurance Coverage in the United States: 2011. U.S. Census Bureau, Current Population Reports. Washington, DC: U.S. Government Printing Office.

Carnevale, Anthony P., Jeff Strohl, and Michelle Melton. 2011. What's It worth? The Economic Value of College Majors. Washington, DC: Georgetown University Center on Education and the Workforce.

Chan, Tak Wing. 1999. "Revolving Doors Reexamined: Occupational Sex Segregation over the Life Course." American Sociological Review, 64(1):86-96.

Chang, Grace. 2000. Disposable Domestics: Immigrant Women Workers in the Global Economy. Boston: South End Press.

Chusseau, Nathalie, Michel Dumont, and Joel Hellier. 2008. "Explaining Rising Inequality: Skill-biased Technical Change and North-South Trade." Journal of Economic Surveys, 22(3):409-57.

Corbett, Christianne, and Chatherine Hill. 2012. "Graduating to a Pay Gap: The Earnings of Women and Men One Year after College Graduation.” American Association of University Women, Washtington, D.C.

Correll, Shelley J. 2001. "Gender and the Career Choice Process: The Role of Biased Self-Assessments.” American Journal of Sociology 106(6):1691-1730.

Darity, William, and Patrick Mason. 1998. "Evidence on Discrimination in Employment: Codes of Color, Codes of Gender." Journal of Economic Perspectives, 12(2):63-90.

de la Luz Ibarra, M.. 2000. "Mexican Immigrant Women and the New Domestic Labor." Human Organization, 59(4):452-64.

Duffy, Ann and Norene Pupo. 1992. Part-time Paradox: Connecting Gender, Work and Family. Toronto: McClelland \& Stewart.

Elliott, James R., and Ryan A. Smith. 2004. "Race, Gender, and Workplace Power." American Sociological Review 69(3):365-86.

England, Paula, and Su Li. 2006. "Desegregation Stalled: The Changing Gender Composition of College Majors, 1971-2002." Gender \& Society 20:657-677.

Fernandez, Roberto M. and Isabel Fernandez-Mateo. 2006. "Networks, Race, and Hiring." 
American Sociological Review 71: 42-71.

Fernandez, Roberto M., and M. Lourdes Sosa. 2005. "Gendering the Job: Networks and Recruitment at a Call Center.” American Journal of Sociology 111(3):859-904.

Gill, Andrew M. 1994. "Incorporating the Causes of Occupational Differences in Studies of Racial Wage Differentials.” Journal of Human Resources, 29:20-41.

Goldin, Claudia, and Cecilia Rouse. 2000. "Orchestrating Impartiality: The Impact of 'Blind' Auditions on Female Musicians." American Economic Review 90: 715-741.

Halaby, Charles N. 2003. "Where Job Values Come from: Family and Schooling Background, Cognitive Ability, and Gender.” American Sociological Review 68(2):251-78.

Hofferth, Sandra L. 1996. "Effects of Public and Private Policies on Working after Childbirth." Work and Occupations 23:378-404.

Hondagneu-Sotelo, Pierrette. 2001. Domestica: Immigrant Workers Cleaning and Caring in the Shadows of Affluence. Berkeley, CA: University of California Press.

Jacobs, Jerry. 1989. Revolving Doors: Sex Segregation and Women's Careers. Stanford: Stanford University Press.

Joech, Jutta. M. 1997. "Paid Leave and Timing of Women's Employment before and after Birth.” Journal of Marriage and the Family 59:1008-21.

Kalleberg, Arne L. 2001. "Organizing Flexibility: The Flexible Firm in a New Century." British Journal of Industrial Relations 39: 479-504.

- 2003. "Flexible Firms and Labor Market Segmentation: Effects of Workplace Restructuring on Jobs and Workers." Work and Occupations 30(2): 154-75.

- 2011. Good Jobs, Bad Jobs: The Rise of Polarized and Precarious Employment Systems in the United States, 1970s to 2000s. New York: Russell Sage Foundation.

Kalleberg, Arne, B. Reskin, K. Hudson. 2000. "Bad jobs in America: Standard and nonstandard employment relations and job quality in the United States." American Sociological Review 65:256-78.

Kanter, Rosabeth Moss. 1977. "Some Effects of Proportions on Group Life: Skewed Sex Ratios and Responses to Token Women.” American Journal of Sociology, 82(5):965-90.

Kim, Marlene. 2013. Policies to End the Gender Wage Gap in the United States. Review of Radical Political Economics 45(3): 278-83.

Leicht, Kevin T. 2008. "Broken Down by Race and Gender? Sociological Explanations of New Sources of Earnings Inequality.” Annual Review of Sociology 34:237-55.

Lettau, Michael K. 1994. "Compensation in Part-Time Jobs versus Full-Time Jobs: hat if the Job is the Same?" Bureau of Labor Statistics, access the article from http://www.bls.gov/ore/abstract/ec/ec940080.htm.

Lin, Nan. 1999. "Social Networks and Status Attainment." Annual Review of Sociology 25: 467-87.

Lopez-Garza, Marta, and David Diaz (eds). 2001. Asian and Latino Immigrants in a Restructuring Economy. Stanford, CA: Stanford University Press.

Marini, Margaret Mooney and Pi-Ling Fan. 1997. "The Gender Gap in Earnings at Career Entry." American Sociological Review 62 (August):588-604.

McCall, Leslie. 2001. Complex Inequality: Gender, Class and Race in the New Economy. New York: Routledge. 
McKinnish, Terra. 2008. "Spousal Mobility and Earnings.” Demography 45(4): 829-49.

Mincer, Jacob and Soloman W. Polachek. 1974. "Family Investments in Human Capital:

Earnings of Women.” Journal of Political Economy, 82: S76-108.

Momsen, J. 1999. Gender, Migration, and Domestic Service. London: Routledge.

Morris, Martina, Annette D. Bernhardt, and Mark S. Handcock. 1994. "Economic Inequality:

New Methods for New Trends.” American Sociological Review, 59:205-19.

Morris, Martina and Bruce Western. 1999. "Inequality in Earnings at the Close of the Twentieth Century." Annual Review of Sociology, 25:623-57.

Neckerman, Kathryn, and Florencia Torche. 2007. "Inequality: Causes and Consequences." Annual Review of Sociology 33:335-57.

Parrenas, R.S.. 2001. Servants of Globalization: Women, Migration, and Domestic Work. Stanford, CA: Stanford University Press.

Petersen, Trond, Ishak Saporta, and Marc-David L. Seidel. 2000. "Offering a Job: Meritocracy and Social Networks.” American Journal of Sociology 106(3):763-816.

Podolny, Joel M. and James N. Baron. 1997. "Resources and Relationships: Social Networks and Mobility in the Workplace." American Sociological Review, 62:673-93.

Reskin, Barbara F. 1988. "Bringing the Men Back In: Sex Differentiation and the Devaluation of Women's Work.." Gender and Society, 2(1):58-81.

—. 1993. "Sex Segregation in the Workplace." Annual Review of Sociology, 19:241-70.

Reskin, Barbara and Debra B. McBrier. 2000. "Why Not Ascription? Organizations'

Employment of Male and Female Managers." American Sociological Review 65(April):210-33.

Reskin, Arne B., and P. Roos. 1990. Job Queues, Gender Queues: Explaining Women's Inroads into Male Occupations. Philadelphia: Temple University Press.

Roos, Patricia A., and Mary L. Gatta. 1999. "The Gender Gap in Earnings: Trends, Explanations, Prospects." Pp. 95-123 in Handbook of Gender and Work, edited by G. N. Powell. Thousand Oaks, Ca: Sage Publications, Inc.

Rubery, Jill, and Anthony Rafferty. 2013. "Women and Recession Revisited." Work, Employment, and Society 27(3): 414-32.

Sassen, Saskia. 1988. The Mobility of Labor and Capital: A Study in International Investment and Labor Flow. Cambridge, MA: Cambridge University Press.

- 1998. Globalization and its Discontents: Essays on the New Mobility of People and Money. New York: New Press.

Smith, Vicki. 1994. "Braverman's Legacy.” Work and Occupations 21: 403-21

Tilly, Chris. 1996. Half a Job: Bad and Good Part-time Jobs in a Changing Labor

Market. Philadelphia: Temple University Press

Tomaskovic-Devey, Donald. 1993. "The Gender and Race Composition of Jobs and the Male/female, White/black Pay Gaps.” Social Forces, 72:45-76.

Tomaskovic-Devey, Donald and Shery I. Skaggs. 2002. "Sex Segregation, Labor Process Organization, and Gender Earnings Inequality." American Journal of Sociology 108(1):102-28.

Tomaskovic-Devey, Donald, Kevin Stainback, Tiffany Taylor, and Catherine Zimmer. 2006. "Documenting Desegregation: Segregation in American Workplaces by Race, Ethnicity, 


\section{Macrothink}

and Sex, 1966-2003." American Sociological Review 71(August): 565-588.

Vernez, Georges. 1999. Immigrant Women in the Workforce: Who Struggles? Who Succeeds? Lanham, MD: Lexington Books.

Weinberg, Bruce. 2000. "Computer Use and the Demand for Female Workers." Industrial and Labor Relations Review 53: 290-308.

Wood, Robert G., Mary E. Corcoran, and Paul N. Courant. 1993. "Pay Differences among the Highly Paid: The Male-Female Earnings Gap in Lawyers' Salaries." Journal of Labor Economics 11(3): 417-441.

Zhang, Yun. 2011. "Recession and Gender Wage Inequality." Presented at the 2011 Fourth International Joint Conference on Computational Sciences and Optimization. 